\title{
Strength training and diet supplementation in the Polish Army on the example of a selected military unit
}

\author{
Marta Tomczyńska-Mleko', Alina Stachula², Wioletta Żukiewicz-Sobczak ${ }^{3}$, Stanisław Mleko², \\ Agnieszka Dylewska² \\ 1 Institute of Plant Genetics, Breeding and Biotechnology, University of Life Sciences in Lublin, Poland \\ ${ }^{2}$ Department of Biotechnology, Human Nutrition and Food Commodity Science, University of Life Sciences in Lublin, Poland \\ ${ }^{3}$ Department of Allergology and Environmental Hazards, Institute of Rural Health in Lublin, Poland
}

Tomczyńska-Mleko M, Stachula A, Żukiewicz-Sobczak W, Mleko S, Dylewska A. Strength training and diet supplementation in the Polish Army on the example of a selected military unit. J Pre-Clin Clin Res. 2013; 7(2): 124-128.

\begin{abstract}
Introduction and objective. Strength training is one of the most important elements to keep soldiers battle ready. The aim of this article was to determine strength training practices and the intake of supplements by Polish Army soldiers. Attitudes toward physical fitness and the level of dietary knowledge among the soldiers were also examined.

Methods. The soldiers ( $\mathrm{N}=82$ ) voluntarily participated in an anonymous survey.

Results. The majority of participants take care of their bodies thanks to sport practice. They trained mainly 3-4 times a week. The results showed that the soldiers had good knowledge about strength training, and were aware that overtraining can induce dangerous consequences. All of the respondents regularly bought supplements because of their composition. Interestingly, no one reported buying creatine or free amino acids. Probably, the respondents were not aware that creatine is considered as the best, legal anabolic compound in use. The soldiers choose mainly protein and protein-carbohydrate supplements, mostly purchased in Internet shops (65\%) and special nutrition shops (20\%). During the training, most of the soldiers (90\%) drank only natural, mineral water, and $10 \%$ used isotonic drinks. $40 \%$ of respondents compose the diet by themselves, using the Internet, and only $23 \%$ follow the advices of their coach.

Conclusions. The presented research shows that soldiers in general are well informed that they need strength training and how to train. However, they should be better educated about how to supplement their diet.
\end{abstract}

\section{Key words}

strength training, soldier, supplement, diet, battle ready

\section{INTRODUCTION}

It is commonly known that sport plays a very important role in maintaining the good health condition of people. Physical exercise besides has effects on muscles and bones, may even prevent structural brain tissue loss, resulting in attenuating declines in executive cognitive function by somewhat enhancing biological mechanisms [1]. Strength training is a very important part of physical activity and is accepted as a component of a healthy and active lifestyle. Unfortunately, most adults in the USA do not participate in strength training activities. In 2003 , only $21 \%$ of US adults participated in strength training activities on at least a 2 days a week basis [2]. In Poland, no results considering strength training among the population have been published; but in general physical activity is less popular in Poland then in the USA. Overall, greater public health efforts are needed to focus on the benefits of strength training, not only on the need of exercise.

Strength training is connected with the lower probability of such disease processes as osteoporosis, cardiovascular disease, and diabetes. In addition to the physical benefits, this kind of activity has a great impact on the psychological

Address for correspondence: Marta Tomczyńska-Mleko, Institute of Plant Genetics, Breeding and Biotechnology, University of Life Sciences in Lublin, Poland e-mail: martamleko@tlen.pl

Received: 06 November 2013; accepted: 04 February 2014 aspect, including positive changes to mood, anxiety levels and better self-efficacy. However, this aspect has largely been ignored in military training [3]. There are many professions in which a high level of physical performance is needed to execute them. One of the most important examples of such populations are soldiers, who are required to develop and maintain high levels of physical fitness as they perform physically demanding tasks [4]. In the scientific literature, the importance of having physically fit soldiers at a mission-ready status is often mentioned [3]. This is why all armies invest a great part of their resources into training their soldiers to be resilient in the face of dangerous tasks. Military populations, as other groups engaged in vigorous physical activity, may suffer from injuries. This is another very important aspect, as these injuries concern the military not only because of their incidence but because they influence on significant loss of personnel resources, and can compromise operational readiness. In 1994, the US Army fatality rate was 87 deaths per 100,000 persons/year, with accidents (unintentional injuries) accounting for $49 \%$ of all deaths. All illnesses and diseases in the US Army accounted for only $18 \%$ of deaths. Because of these frequent injuries, the US Army developed a comprehensive injury prevention program [4]. Strength training may prevent at least some part of these injures and improve condition of the Army. In 1994 in the US Army, among the most common category of injuries needing the hospitalization of personnel were digestive diseases [4]. For that reason, a soldier's diet should be verified in all armies, 
including the Polish Army, and for better strength training, diet supplements should be used.

The aim of this article is to determine the attitude to strength training practices and supplements intake in soldiers of the Polish Army.

\section{METHODS}

Screening process. Approval was obtained from the brigade commanders. The survey was distributed to the soldiers of one brigade combat team in southeastern Poland. Soldiers were introduced to the general subject of the survey they would be completing, and that the survey was voluntary and anonymous. Soldiers were informed that there would be no negative consequences for non-participation. Upon completion, the survey forms were collected and delivered for evaluation. After completion of the survey, the soldiers returned to their normal duties.

Content of the survey. The survey was divided into three parts. The first part was a demographic section. The remaining two parts concerned attitudes to strength training and intake of different diet supplements. Soldiers could choose only one answer for each question. The number of possible answers were different and depended on the character of the question.

Demographic information. Soldiers were asked to provide basic demographic information, including gender and age. Into the question about age, answers were divided into groups from 20 - 40 years old.

Attitudes towards sport. Soldiers were presented with a group of questions connected with their physical activities. Firstly, they were asked, how they took care of their bodies. Choices included sport practice, good dietary habits, or any cosmetic procedures of the body. Soldiers were also asked some psychological questions, such as: How important is physical appearance for you?'. Possible reply choices were: 'Very important as I want to be well-perceived by others', 'rather important' or 'of little importance; I prefer to devote my time to other things'. In the question connected with the reasons for training in the gym, possible answers were as follows: 'For better appearance', 'To increase physical strength', 'To increase self-confidence', 'My job requires that from me', 'In order to be more attractive for girls/boys' and 'for my health'. The soldiers were also asked about their frequency of training in the gym. Choices ranged from: 'Once or twice a month' to 'everyday'. In addition, there were also two questions about the subjective estimation of the soldier's silhouette before training, and actual self-estimation when training was implemented.

Supplements in the soldier's diet. The last part of the survey concerned soldiers' knowledge about diet supplementation and their usage of different products available on the Polish market. Firstly, soldiers were asked about their information sources about how to train. Options to choose were: 'The Internet', 'older friends', 'newspapers', and finally: 'My coach in the gym'. The next question referred to the frequency of buying diet supplements and nutrients among the Polish soldiers. The answers ranged from: 'Once a month' to 'Once a year'. Soldiers were also asked about the average amount of money spent on nutrients per month. Choices were from 'less than $\$ 15$ ' to '\$100-150'. Respondents also had to mark which factors were decisive when choosing a supplement/ nutrient. The factors included: price, brand, composition, taste, advice from a friend, opinion on the Internet, or advice from their coach.

The next question was to assess the soldiers' knowledge about the right diet: 'Which products are bought the most often by the soldiers?' Answers included: 'Protein nutrients', 'Protein-carbohydrate nutrients', 'Carbohydrate nutrients', 'Creatine', 'Amino acids' or 'Vitamins complex'. The respondents then chose the preferred brand of nutrient and isotonic beverage, and gave information about where they did their shopping.

Other questions were: 'What do you drink during the training?' and 'How do you compose your diet?' Answers to the second question: 'By myself, using the Internet', 'Thanks to the opinions on the Internet forum', 'Thanks to articles in sports magazines', 'Thanks to the advice of my coach', and finally, 'After consultation with my friends'. The last two questions concerned the soldiers' opinion on nutrients and isotonic beverages - 'Are they needed for the health of people?' and 'Are they available enough?'. For these questions, the answers were either 'Yes' or 'No'.

\section{RESULTS}

82 soldiers from a military unit in southeastern Poland were asked to take part in the survey concerning strength training activities and diet supplementation in the Polish Army. All the recruits (100\%) voluntarily agreed to participate. The population was male only, because there were no women recruited in the chosen military unit. Age data of the recruits are given in Table 1.

Table 1. Age of the soldiers

\begin{tabular}{lcc}
\hline \multicolumn{1}{c}{ Age of the soldiers } & No. of responds & Percentage \\
\hline $20-25$ years & 10 & 12 \\
\hline $25-30$ years & 21 & 25 \\
\hline $30-35$ years & 39 & 48 \\
\hline $35-40$ years & 12 & 15 \\
\hline$>40$ years & 0 & 0
\end{tabular}

Many (80\%) of the soldiers answered that they took care of their bodies thanks to sport practice. $20 \%$ of the participants stated that they had good dietary habits. No one $(0 \%)$ indicated the use of special cosmetic procedures.

To the question about the importance of physical appearance, almost everyone (95\%) noted that it was 'Rather important'; only $5 \%$ of soldiers claimed that being goodlooking was very important for them as they want to be well-perceived by others.

Table 2 summarizes the soldiers' reasons for training in the gym. Almost half of the respondents (42\%) reported that they had to be fit because of their job. Interestingly, a quarter of soldiers admitted that they wanted to be fit in order to be more attractive to other people.

Table 3outlines how often the soldiers trained in the gym. The majority (60\%) trained $3-4$ times a week, the rest trained twice a week. These results show that the soldiers 
Table 2. Reasons for training in the gym

\begin{tabular}{lcc}
\hline \multicolumn{1}{c}{ Reason for training } & No. of responds & Percentage \\
\hline - for better appearance & 0 & 0 \\
\hline - to increase physical strength & 16 & 18 \\
\hline - to increase self-confidence & 0 & 0 \\
\hline - my job requires it from me & 34 & 42 \\
\hline - in order to please girls/boys & 20 & 25 \\
\hline - for my health & 12 & 15 \\
\hline
\end{tabular}

Table 3. Frequency of strength training

\begin{tabular}{lcc}
\hline Frequency of training in the gym & No. of responds & Percentage \\
\hline - once or twice a month & 0 & 0 \\
\hline - twice a week & 33 & 40 \\
\hline - 3-4 times a week & 49 & 60 \\
\hline - every day & 0 & 0 \\
\hline
\end{tabular}

had good knowledge about strength training, and were aware that overtraining can induce dangerous consequences. In responding to the question on the subjective opinion of self silhouette before strength training, $70 \%$ of respondents reported that they were neither too fat nor too slim. 30\% indicated that they were overweight. When actual estimation were taken into consideration, $85 \%$ of soldiers unfortunately agreed that they looked only a little bit better because of strength training; only $10 \%$ claimed that they we now more muscular, and 5\% did not see any changes in their bodies. $35 \%$ of soldiers followed their coach's advice about how to train; 33\% found the information from newspapers and 32\% used the Internet. Half of the respondents (50\%) bought supplements and nutrients once a quarter; $38 \%$ bought them once every two months, and $12 \%$ once a month. Only $20 \%$ of respondents admitted that they spent, on average, less than $\$ 15$ per month on nutrients, and $80 \%$ of soldiers agreed that they spent, on average, \$15-40. In spite of that fact, for 70\% of respondents, the most important factor when buying a supplement/nutrient was its composition; $20 \%$ of respondents chose it because of the price; $5 \%$ pointed out their coach's advice and $5 \%$ a friend's advice, respectively.

Table 4 outlines the supplements used among Polish soldiers. Protein and protein/carbohydrate supplements were the most often bought (altogether 76\%). Interestingly, no one reported using creatine as a diet supplement. The respondents were probably unaware that creatine is considered as the best, legal anabolic compound in use, and is responsible for muscle growth in a relative short period of time. Creatine improves strength and endurance and should be used by soldiers. The preferred brand of nutrient for $75 \%$ of soldiers was Olimp. 20\% of respondents chose Activia; 5\% reported

Table 4. Supplements most often chosen by soldiers

\begin{tabular}{lcc}
\hline \multicolumn{1}{c}{ Products bought most often } & No. of responds & Percentage \\
\hline - protein nutrients & 30 & 37 \\
\hline - protein-carbohydrate nutrients & 32 & 39 \\
\hline - carbohydrate nutrients & 8 & 10 \\
\hline - creatine & 0 & 0 \\
\hline - amino acids & 0 & 0 \\
\hline - vitamins' complex & 12 & 15 \\
\hline
\end{tabular}

the mark Hi-tec, and as for isotonic beverages, $42 \%$ noted the brand Isostar; $40 \%$ prefered brand Powerade and 18\% chose ISOdrinx (brand Nutrend). During the training, most of the soldiers (90\%) drank only natural, mineral water and $10 \%$ use isotonic drinks.

Table 5 shows the ways in which the supplements were purchased. $65 \%$ of respondents did their shopping on the Internet; $20 \%$ reported going to a special shop selling nutrients; 7\% choose the Polish auction portal 'Allegro', $5 \%$ went to a sports shop, and $4 \%$ bought nutrients in a hypermarket.

Table 5. Way which supplements were purchased

\begin{tabular}{lcc}
\hline \multicolumn{1}{c}{ Way of purchase } & No. of responds & Percentage \\
\hline Internet shops & 53 & 65 \\
\hline Nutrition shops & 16 & 20 \\
\hline Internet auction portal 'Allegro' & 6 & 7 \\
\hline Sport shops & 4 & 5 \\
\hline Hypermarkets & 3 & 4 \\
\hline
\end{tabular}

The source of knowledge about sport nutrition is shown in Table $6.40 \%$ of respondents composed the diet by themselves, using the Internet; $23 \%$ followed the advices of their coach; $20 \%$ profited from sport magazines, $15 \%$ consulted with friends; while only $2 \%$ followed the opinions from Internet forum. All of the respondents (100\%) reported that both nutrients and isotonic beverages were necessary, that they were healthy for people and sufficiently available (Tab. 7).

Table 6. Source of knowledge about sport diet

\begin{tabular}{lcc}
\hline \multicolumn{1}{c}{ Source of knowledge } & No. of responds & Percentage \\
\hline Internet websites & 33 & 40 \\
\hline Gym coach & 19 & 23 \\
\hline Sports magazines & 16 & 20 \\
\hline Members of the gym & 12 & 15 \\
\hline Internet forum & 2 & 2
\end{tabular}

Table 7. Soldiers' opinions about nutrients and isotonic beverages

\begin{tabular}{lcclll}
\hline \multicolumn{1}{c}{$\begin{array}{c}\text { Opinion about } \\
\text { Nutrients }\end{array}$} & YES & NO & $\begin{array}{l}\text { Opinion about } \\
\text { isotonic beverages }\end{array}$ & YES & NO \\
\hline Are they needed? & $100 \%$ & $0 \%$ & Are they needed? & $100 \%$ & $0 \%$ \\
\hline $\begin{array}{l}\text { Are they healthy for } \\
\text { people? }\end{array}$ & $100 \%$ & $0 \%$ & $\begin{array}{l}\text { Are they healthy } \\
\text { for people? }\end{array}$ & $100 \%$ & $0 \%$ \\
\hline $\begin{array}{l}\text { Are they available } \\
\text { enough? }\end{array}$ & $100 \%$ & $0 \%$ & $\begin{array}{l}\text { Are they available } \\
\text { enough? }\end{array}$ & $100 \%$ & $0 \%$ \\
\hline
\end{tabular}

\section{DISCUSSION}

Attitudes toward strength training. Strength training is well-known and applied broadly by Polish soldiers. For almost every soldier (95\%), good physical appearance was 'rather important', and soldiers want to be fit for different reasons (Table 2). Once a year, all Polish soldiers have a fitness and strength examination. An ordinary soldier must pull up on a bar 14 times per minute, for commandos 18 times. A commando has 6 hours of physical education per week. Strength training is not obligatory, but it is becoming 
more and more popular in the Polish Army; most Polish Military Units already have gyms and many are in the process of equipping them with more advanced strength training machines. Research by other authors shows that the more men are involved in weight training activities, the more satisfied they are with their bodies [5]. The majority of polled Polish soldiers train 3-4 times a week, which is a satisfactory result. There were no soldiers who practiced strength training rarely or irregularly. In most cases, soldiers report that before starting strength training, they were neither too fat nor too slim, while $30 \%$ indicated that they were overweight. Ominously, $85 \%$ of soldiers claim that they looked 'only a bit better' currently, and 5\% did not notice any changes. What is interesting is that research on body image and body satisfaction shows that young men tend to see themselves as thinner and less muscular than they really are [5]. This was also probably the case in the presented study. For approximately $40 \%$ of respondents, the main source information on how to train was the Internet. Undoubtedly, they should be given such information from more professional sources.

Supplements' users. All the soldiers reported buying supplements or nutrients regularly. For many of them, the composition of a supplement played the main role. As the market of supplements is enormous, it is hard to find the best solution. Opinions between soldiers were also divided. Surprisingly, no one purchase creatine which is generally known as the best anabolic compound. It also indicates that the soldiers should be better informed by specialist trainers. People with special physical needs are major consumers of dietary supplements and specialized sports foods [6]. Creatine monohydrate, for instance, is widely used by élite Australian power lifters: $74 \%$ identified themselves in a questionnaire as current or former users, and only $26 \%$ as non-users [7]. Power lifters agree that creatine improved their competitive performance and quality of training. The most common effect was an increase in muscle mass. Polish soldiers use mostly protein-carbohydrate and protein supplements. According to Duellman et al., protein supplements are ingested widely by athletes to improve agility, strength and speed [8].

The authors emphasize that 'to- date, no studies have shown an advantage of ingesting protein supplements over natural, protein-containing foods; therefore, the dietary sources of protein may be just as effective as protein supplemental sources in the regulation of muscle protein synthesis'. The authors also claim that nutrition information sources can be inadequate and cause misconceptions of protein supplement effectiveness [8]. Other authors, however, who researched nutritional practices of male and female endurance cyclists, found that the mean daily intakes of protein reported by male cyclists met or exceeded the estimated protein needs of athletes undertaking a substantial training load (0.7 $0.9 \mathrm{~g} /$ pound) $[6,9]$. These findings show that in different sportive populations, exceeding protein supplementation is very common.

There are many possible risks of long-term high protein intake: dehydration, gout, urinary calcium loss, renal damage, diarrhea, bloating, atherosclerosis, and colon cancer. These probable side-effects are still being explored by researchers [8]. Soldiers should also be informed about the appropriate intake of carbohydrates. The availability of carbohydrates as a substrate for muscle and the central nervous system is a critical factor in the performance of prolonged sessions ( $>60$ minutes) of endurance training exercise, and it also crucial for the performance of brief, high-intensity strength training [10]. In the presented research, soldiers composed their diet mainly by themselves, using the Internet. Special education programmes should be incorporated in their training, allowing them to extend the knowledge on sport supplementation. Supplementation should also be controlled, nutrients deficiency should be detected by regular blood tests.

Currently, about 1,700 women serve in Polish Army; almost half of them are officers, approximately 700 serve as NCOs, and over 200 are privates. Most of them (more than 700) wear army uniform. More than 300 women serve in Air Force and about 100 in the Navy. Women also serve in the Military Police units, logistical support and military health care. The US military comprises $>15 \%$ women, which amounts to $>341,000$ individuals. Strength training should also be implemented into the regular service schedule of female military personnel. Proper supplementation and diet for female soldiers is very important as women have special needs, e.g. concerning iron supplementation [11].

There are special guidelines for the US Army that emphasize fluid replacement during hot weather training to minimize the risk of heat injury and prevent the degradation of performance. The authors demonstrate an increasing incidence of water intoxication during military training [12]. The Polish Army should also investigate the amounts of fluids that should be consumed by soldiers and promote the use of water and isotonic beverages.

The Wisconsin Army National Guard in the USA has developed a program to protect the soldiers from the risk of failing weight and fitness standards. Instruction include topics on exercise training, nutrition, general wellness, stress reduction, and motivational lectures [13]. Special educational programs should be incorporated in Polish military units, to increase soldiers' knowledge about strength and fitness training methods, and proper supplementation.

\section{CONCLUSIONS}

A reasonable diet, adequate for the soldiers' needs is the best method to prevent deficits of nutrients. Soldiers in need of diet supplementation should consult beforehand with a nutritionist, and follow the supplementation only until the deficiency of nutrients is rectified. A suitable supplement should also be decided in consultation with a specialist. The presented study shows that, in general, soldiers are well informed about how to train and consequently they are physically fit. However, they should also be educated about how to supplement their diet and how to train.

\section{REFERENCES}

1. Kimura K, Obuchi S, Arai T, Nagasawa H, Shiba Y, Watanabe S, Kojima M. The Influence of Short-term Strength Training on Health-related Quality of Life and Executive Cognitive Function. J Physiol Anthropol. 2010; 29: 95-101.

2. Chevan J. Demographic Determinants of Participation in Strength Training Activities among U. S. Adults. J Strength Cond Res. 2008; 22(2): 553-558.

3. Thomas JL, Adler AB, Wittels P, Enne R, Johannes B. Comparing Elite Soldiers' Perceptions of Psychological and Physical Demands during Military Training. Milit Med. 2004; 169(7): 526-530. 
4. Jones BH, Knapik JJ. Physical Training and Exercise-Related Injuries. Sports Med. 1999; 27(2): 111-125.

5. McCreary DR, Sasse DK. An Exploration of the Drive for Muscularity in Adolescent Boys and Girls. J Am Coll Health. 2000; 48: 297-304.

6. Burke LM. Nutritional Practices of Male and Female Endurance Cyclists. Sports Med. 2001; 31(7): 521-532.

7. Stanton R. Creatine monohydrate use among elite Australian power lifters. J Strength Cond Res. 2000; 14(3): 322-327.

8. Duellman MC, Lukaszuk JM, Prawitz AD, Brandenburg JP. Protein Supplement Users Among High School Athletes Have Misconceptions about Effectiveness. J Strength Cond Res. 2008; 22(4): 1124-1129.

9.Lemon PW. Effect of exercise on protein requirements. J Sports Sci 1999; 9: 53-70
10. Burke LM, Cox GR, Cummings NK, Desbrow B. Guidelines for Daily Carbohydrate Intake. Sports Med. 2001; 31(4): 267-299.

11. McClung JP, Karl JP, Cable SJ, Williams KW, Nindl BC, Young AJ, Lieberman HR. Randomized, double-blind, placebo-controlled trial of iron supplementation in female soldiers during military training: effects on iron status, physical performance, and mood. Am J Clin Nutr. 2009; 90: 124-31.

12. Montain SJ, Latzka WA, Sawka MN. Fluid Replacement Recommendations for Training in Hot Weather. Milit Med. 1999; 164(7): 502-508

13. Lalich RA. An Initiative to Retain Reserve Soldiers Failing To Meet Weight and Physical Fitness Standards: The Wisconsin Army National Guard Experience. Milit Med. 2001; 166(3): 204-207. 